\title{
Optimization of lipase-catalyzed synthesis of xylitol ester by Taguchi robust design method.
}

\begin{abstract}
Enzymatic synthesis of xylitol fatty acid ester was performed in hexane using Novozym 435 (immobilized Candida antarctica lipase on macroporous resin). Taguchi method based on three levels, six variables L27 orthogonal array robust design was implemented to optimize experimental conditions. The effects of reaction parameters including reaction time $(7-24 \mathrm{~h})$, enzyme amount $(0.05-0.3 \mathrm{~g})$, temperature $\left(30-60{ }^{\circ} \mathrm{C}\right)$, amount of molecular sieve $(1-4 \mathrm{~g})$, substrate molar ratio $(0.3-1)$ and xylitol concentration $(0.005-0.015 \mathrm{~g} / \mathrm{ml})$ on the percentage yield of sugar ester were investigated. The optimum conditions derived via Taguchi method were: reaction time $7 \mathrm{~h}$, temperature $60{ }^{\circ} \mathrm{C}$, amount of enzyme $0.12 \mathrm{~g}$, amount of molecular sieve $2.5 \mathrm{~g}$, substrate molar ratio 1 and xylitol concentration $0.015 \mathrm{~g} / \mathrm{ml}$. The actual experimental yield was $96.10 \%$ under optimum condition, which compared well to the maximum predicted value of $96.27 \%$.
\end{abstract}

Keyword: Xylitol ester; Lipase; Optimization; Taguchi method; Statistical experimental design. 